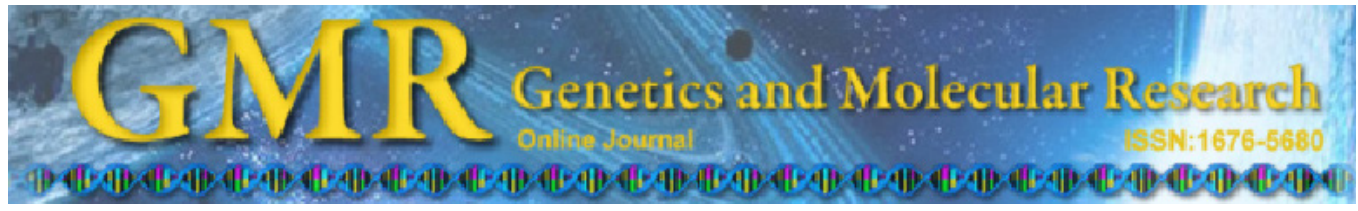

$\underline{\text { Research Article }}$

\title{
Isolation and characterization of polymorphic microsatellite loci from aerial yam (Dioscorea bulbifera L.)
}

Q.Q. Yan, Y. Li, X.Q. Sun, J.L. Guo, Y.Y. Hang and M.M. Li

Jiangsu Provincial Key Laboratory for Plant Ex Situ Conservation, Institute of Botany, Jiangsu Province and Chinese Academy of Sciences, Nanjing, China

Corresponding authors: M.M. Li / Y.Y. Hang

E-mail: limm001@163.com / hangyueyu@yahoo.com.cn

Genet. Mol. Res. 13 (1): 1514-1517 (2014)

Received December 7, 2012

Accepted June 28, 2013

Published March 12, 2014

DOI http://dx.doi.org/10.4238/2014.March.12.3

\begin{abstract}
Dioscorea bulbifera L. is widely distributed in pantropical regions along the equator. The taxonomic treatment of this species is ambiguous due to its extreme polymorphic morphological characters. In order to provide tools to facilitate the study of genetic diversity, population structure, patterns of gene flow, and the mating system of this species, and to assess intraspecific variability and relationships in D. bulbifera, 14 novel polymorphic microsatellite loci were developed using the dualsuppression PCR technique. The number of alleles per locus ranged from 4 to 17 , with an average of 9.93 . The mean observed heterozygosities were 0.7327 and 0.7223 , and the mean Shannon-Wiener indices were 1.6431 and 1.811 in the Nanjing and Nanchong populations, respectively. All novel microsatellite loci showed high levels of polymorphism, indicating that these markers offer great potential significance and profound influence for future studies of this species.
\end{abstract}

Key words: Dioscorea bulbifera L.; Genetic diversity; SSRs; Microsatellite loci; Taxonomic delimitation 


\section{INTRODUCTION}

The aerial yam, Dioscorea bulbifera L. (family Dioscoreaceae) is widely distributed in pantropical regions along the equator (Ting et al., 1985; Ting and Michael, 2000). In China, it is considered to have medicinal properties, is widely used in traditional Chinese medicine (Ting et al., 1978), and is cultured as foodstuffs in some areas because of its edible bulbils (Lebot, 2009), whereas in North America, it is treated as an invasive weed (Croxton et al., 2011).

D. bulbifera is polyploid, with $\mathrm{n}=9$ seen in Africa and in the Americas and $\mathrm{n}=10$ in Asia (Martin and Ortiz, 1963). The taxonomic treatment of this species is ambiguous due to its extreme polymorphic morphological characteristics (Ramser et al., 1996). Hence, in this study, we developed and characterized a set of microsatellite loci (simple sequence repeats, SSRs) for D. bulbifera, to serve as tools for studying the genetic diversity, population structure, patterns of gene flow, and mating system of this species and to assess intraspecific variability and relationships in D. bulbifera.

\section{MATERIAL AND METHODS}

D. bulbifera plants were collected from 2 tetraploid populations; the Nanjing population in Jiangsu province and the Nanchong population in Sichuan province. Voucher specimens for the sampled populations have been deposited in the Herbarium of the Institute of Botany, Jiangsu Province, and the Chinese Academy of Sciences (NAS). Genomic DNA isolation was carried out using a modification of the hexadecyltrimethylammonium bromide (CTAB) method (Doyle, 1991). One individual from the Nanjing population was selected for digestion with the EcoRV restriction enzyme (Takara, Dalian, China) in order to construct a DNA library for D. bulbifera. After digestion, the fragments were ligated with a specific blunt adaptor (consisting of the upper strand 5'-GTAATA CGA CTC ACT ATA GGG CAC GCG TGG TCG ACG GCC CGG GCT GGT-3' and the lower strand, with the 3'-end capped with an amino residue: 5'-ACC AGC CC-3') by T4 DNA ligase (Takara). Subsequently, the fragments were PCR-amplified from the EcoRV DNA library using the compound SSR primer $(\mathrm{AC})_{6}(\mathrm{AG})_{5}$ or $(\mathrm{TC})_{6}(\mathrm{AC})_{5}$ and an $\mathrm{AP}_{2}$ adaptor (5'-CTA TAG GGC ACG CGT GGT-3'). Each 50- $\mu$ L PCR reaction contained 25-50 ng genomic DNA, 1X PCR buffer with $\mathrm{MgCl}_{2}, 0.2 \mathrm{mM}$ each dNTP, $0.5 \mathrm{U}$ Ex Taq polymerase (Takara), and $0.5 \mathrm{mM}$ each compound SSR primer and $\mathrm{AP}_{2}$. The $\mathrm{PCR}$ amplification conditions were as follows: 1 cycle of 9 min at $94^{\circ} \mathrm{C}, 30 \mathrm{~s}$ at $62^{\circ} \mathrm{C}$, and $1 \mathrm{~min}$ at $72^{\circ} \mathrm{C} ; 5$ cycles each of $30 \mathrm{~s}$ at $94^{\circ} \mathrm{C}, 30 \mathrm{~s}$ at $62^{\circ} \mathrm{C}$, and $1 \mathrm{~min}$ at $72^{\circ} \mathrm{C} ; 35$ cycles each of $30 \mathrm{~s}$ at $94^{\circ} \mathrm{C}, 30 \mathrm{~s}$ at $60^{\circ} \mathrm{C}$, and $1 \mathrm{~min}$ at $72^{\circ} \mathrm{C}$; ending with a final cycle of $30 \mathrm{~s}$ at $94^{\circ} \mathrm{C}, 30 \mathrm{~s}$ at $60^{\circ} \mathrm{C}$, and $9 \mathrm{~min}$ at $72^{\circ} \mathrm{C}$. The products were purified using a DNA clean-up kit (Axygen, Union, CA, USA) and transformed into competent DH5 $\alpha$ cells (Takara) after ligation with the pMD 19-T vector (Takara). A single clone was checked using the M13-47 (5'-CGC CAG GGT TTT CCC AGT CAC GAC-3')/RV-M (5'-GAG CGG ATA ACA ATT TCA CAC AGG-3') universal primers. Positive clones were obtained and sequenced on an ABI Prism 3730 automated DNA sequencer (Applied Biosystems, Foster City, CA, USA). Specific primers were designed based on sequences flanking the compound SSR primers using Primer Premier 5.0 (Clarke and Gorley, 2001).

The designed primers were used to amplify microsatellite repeats from 47 D. bulbifera individuals from the 2 sampled populations. In order to evaluate their levels of polymorphism, the compound SSR primers were labeled with fluorescent dyes (6-FAM or HEX). The amplified products were analyzed by fluorescence capillary electrophoresis on an ABI Prism 3730 automated DNA sequencer (Applied Biosystems). The data were compiled and scored using GeneMaker 1.95 
(Soft-Genetics, State College, PA, USA). The number of alleles $\left(N_{\mathrm{A}}\right)$, observed heterozygosities $\left(H_{\mathrm{O}}\right)$, and Shannon-Wiener index $\left(H^{\prime}\right)$ were determined using ATETRA (Puyvelde et al., 2010).

\section{RESULTS}

In total, 14 microsatellite loci were identified (Table 1). The number of alleles per locus ranged from 4 to 17 , with an average of 9.93. The $H_{\mathrm{O}}$ and $H^{\prime}$ values ranged from 0.3046 to 0.8353 and 0.5667 to 2.1287 , respectively, in the Nanjing population, and from 0.3914 to 0.9041 and 0.7802 to 2.3365 , respectively, in the Nanchong population (Table 2).

\begin{tabular}{|c|c|c|c|c|c|c|}
\hline Locus & Primer sequence $\left(5^{\prime}-3^{\prime}\right)$ & Repeat motif & $\mathrm{Ta}\left({ }^{\circ} \mathrm{C}\right)$ & Size (bp) & $N_{\mathrm{A}}$ & Accession No. \\
\hline$\overline{\text { DBSSR1 }}$ & $\begin{array}{l}\text { F: ACACACACACACAGAGAGAGAG } \\
\text { R: AGAAGTTTGTTGCCCGTC }\end{array}$ & $(\mathrm{AC})_{6}(\mathrm{AG})_{20} \ldots(\mathrm{GGA})_{3}$ & 54 & 215 & 9 & JX908765 \\
\hline DBSSR2 & $\begin{array}{l}\text { F: ACACACACACACAGAGAGAGAG } \\
\text { R: AACGCATCCCACCACTTC }\end{array}$ & $(\mathrm{AC})_{6}(\mathrm{AG})_{13}$ & 54 & 199 & 13 & JX908766 \\
\hline DBSSR3 & $\begin{array}{l}\text { F: ACACACACACACAGAGAGAGAG } \\
\text { R: CACGATGGAGGAACACTT }\end{array}$ & $(\mathrm{AC})_{6}(\mathrm{AG})_{19}$ & 54 & 265 & 12 & JX908767 \\
\hline DBSSR4 & $\begin{array}{l}\text { F: ACACACACACACAGAGAGAGAG } \\
\text { R: GAAAAGGAGAAGCCGAAT }\end{array}$ & $(\mathrm{AC})_{6}(\mathrm{AG})_{9}$ & 54 & 206 & 4 & JX908768 \\
\hline DBSSR5 & $\begin{array}{l}\text { F: ACACACACACACAGAGAGAGAG } \\
\text { R: TTGATTGAAAAGGAGGCT }\end{array}$ & $(\mathrm{AC})_{6}(\mathrm{AG})_{9}$ & 54 & 235 & 12 & JX908769 \\
\hline DBSSR6 & $\begin{array}{l}\text { F: ACACACACACACAGAGAGAGAG } \\
\text { R: GAACAATGCAAATCAGTAAA }\end{array}$ & $(\mathrm{AC})_{6}(\mathrm{AG})_{11}$ & 54 & 136 & 12 & JX908770 \\
\hline DBSSR7 & $\begin{array}{l}\text { F: ACACACACACACAGAGAGAGAG } \\
\text { R: GCAAATCGTGCGAAATAC }\end{array}$ & $(\mathrm{AC})_{6}(\mathrm{AG})_{7}(\mathrm{AC})_{8} \ldots(\mathrm{AG})_{7}$ & 52 & 369 & 14 & JX908771 \\
\hline DBSSR8 & $\begin{array}{l}\text { F: TCTCTCTCTCTCACACACACAC } \\
\text { R: TGACGGAGAACTACAAGC }\end{array}$ & $(\mathrm{TC})_{6}(\mathrm{AC})_{13}$ & 48 & 279 & 17 & JX908772 \\
\hline DBSSR9 & $\begin{array}{l}\text { F: ACACACACACACAGAGAGAGAG } \\
\text { R: TCCTTGGTCCTTGAACTT }\end{array}$ & $(\mathrm{AC})_{6}(\mathrm{AG})_{15}$ & 48 & 85 & 8 & JX908773 \\
\hline DBSSR10 & $\begin{array}{l}\text { F: ACACACACACACAGAGAGAGAG } \\
\text { R: AGAAGTTTGTTGCCCGTC }\end{array}$ & $(\mathrm{AC})_{6}(\mathrm{AG})_{22}$ & 54 & 219 & 8 & JX908774 \\
\hline DBSSR11 & $\begin{array}{l}\text { F: ACACACACACACAGAGAGAGAG } \\
\text { R: TGATTCAGATAAGCCAAAC }\end{array}$ & $(\mathrm{AC})_{6}(\mathrm{AG})_{19}$ & 48 & 121 & 9 & JX908775 \\
\hline DBSSR12 & $\begin{array}{l}\text { F: ACACACACACACAGAGAGAGAG } \\
\text { R: TTGCTTTACCGACATCCA }\end{array}$ & $(\mathrm{AC})_{6}(\mathrm{AG})_{10}$ & 53 & 241 & 6 & JX908776 \\
\hline DBSSR13 & $\begin{array}{l}\text { F: TCTCTCTCTCTCACACACACAC } \\
\text { R: AACAGCCCACCGACTAAA }\end{array}$ & $(\mathrm{TC})_{6}(\mathrm{AC})_{6}$ & 54 & 189 & 11 & JX908777 \\
\hline DBSSR14 & $\begin{array}{l}\text { F: TCTCTCTCTCTCACACACACAC } \\
\text { R: TCTAAGGAGCAGCCGAAT }\end{array}$ & $(\mathrm{TC})_{6}(\mathrm{AC})_{6}$ & 50 & 214 & 4 & JX908778 \\
\hline
\end{tabular}

$\mathrm{Ta}=$ annealing temperature.

Table 2. Results of initial primer screening in two populations of Dioscorea bulbifera.

\begin{tabular}{|c|c|c|c|c|c|c|}
\hline \multirow[t]{2}{*}{ Locus } & \multicolumn{3}{|c|}{ NanJing $(\mathrm{N}=26) 32.03^{\circ} \mathrm{N}, 118.46^{\circ} \mathrm{E}$} & \multicolumn{3}{|c|}{ NanChong $(\mathrm{N}=21) 30.49^{\circ} \mathrm{N}, 106.04^{\circ} \mathrm{E}$} \\
\hline & $N_{\mathrm{A}}$ & $H_{\mathrm{O}}$ & $H^{\prime}$ & $N_{\mathrm{A}}$ & $H_{\mathrm{O}}$ & $H^{\prime}$ \\
\hline$\overline{\text { DBSSR1 }}$ & 7 & 0.8191 & 1.8736 & 7 & 0.7683 & 1.6215 \\
\hline DBSSR2 & 11 & 0.8243 & 1.9419 & 9 & 0.8256 & 1.9148 \\
\hline DBSSR3 & 6 & 0.7811 & 1.6523 & 11 & 0.8765 & 2.2269 \\
\hline DBSSR4 & 4 & 0.4953 & 0.9397 & 3 & 0.5540 & 0.8898 \\
\hline DBSSR5 & 8 & 0.7722 & 1.7585 & 12 & 0.8912 & 2.3365 \\
\hline DBSSR6 & 9 & 0.7370 & 1.6618 & 12 & 0.8900 & 2.3148 \\
\hline DBSSR7 & 13 & 0.8350 & 2.1287 & 14 & 0.9041 & 2.4631 \\
\hline DBSSR8 & 11 & 0.7663 & 1.8548 & 13 & 0.8786 & 2.3510 \\
\hline DBSSR9 & 7 & 0.7035 & 1.3949 & 8 & 0.6292 & 1.3389 \\
\hline DBSSR10 & 8 & 0.7931 & 1.7747 & 7 & 0.7523 & 1.6010 \\
\hline DBSSR11 & 8 & 0.8353 & 1.8954 & 8 & 0.8330 & 1.8813 \\
\hline DBSSR12 & 6 & 0.7728 & 1.6152 & 6 & 0.7748 & 1.6124 \\
\hline DBSSR 13 & 10 & 0.8236 & 1.9447 & 10 & 0.8408 & 2.0278 \\
\hline DBSSR14 & 3 & 0.3046 & 0.5667 & 4 & 0.3914 & 0.7802 \\
\hline Mean & 7.30 & 0.7327 & 1.6431 & 8.86 & 0.7223 & 1.8114 \\
\hline
\end{tabular}

$\mathrm{N}=$ sample size for each population. 


\section{DISCUSSION}

All novel microsatellite loci isolated from D. bulbifera in the present study showed high levels of polymorphism, indicating that these markers will be of great potential significance and profound influence in future research related to the genetic diversity, population structure, patterns of gene flow, and mating system of this species. Furthermore, the microsatellites developed herein will contribute toward better taxonomic delimitation for the aerial yam.

\section{ACKNOWLEDGMENTS}

Research supported by a grant from the Main Direction Program of Knowledge Innovation of the Chinese Academy of Sciences (\#KSCX2-YW-Z-028). The authors thank Mr. Bin Peng for his kind help in the field.

\section{REFERENCES}

Clarke KR and Gorley RN (2001). Primer v5: User Manual/Tutorial. Primer-E Ltd., Plymouth.

Croxton MD, Andreu MA, Williams DA, Overholt WA, et al. (2011). Geographic origins and genetic diversity of airpotato (Dioscorea bulbifera) in Florida. Invasive Plant Sci. Manag. 1: 22-30.

Doyle JJ (1991). DNA Protocols for Plants. In: Molecular Techniques in Taxonomy (Hewitt GM and Johnston A, eds.). Springer-Verlag, Berlin.

Lebot V (2009). Tropical Root and Tuber Crops Cassava, Sweet Potato, Yams and Aroids. Crop Production Science in Horticulture Series.

Martin FW and Ortiz S (1963). Chromosome number behaviour in some species of Dioscorea. Cytologia 28: 96-101.

Puyvelde VK, Geert VA and Triest L (2010). ATETRA, a new software program to analyse tetraploid microsatellite data: comparison with TETRA and TETRASAT. Mol. Ecol. Resour. 10: 331-334.

Ramser J, Weising K, Kahl G, Lopez-Peralta C, et al. (1996). Genomic variation and relationships in aerial yam (Dioscorea bulbifera L.) detected by random amplified polymorphic DNA. Genome 39: 17-25.

Ting CT and Michael GG (2000). Dioscorea Linnaeus. In: Flora of China (Wu ZY and Raven PH, eds.). St. Louis, Missouri Botanical Garden Press, Science Press Beijing.

Ting CT, Chang MC and Ling PP (1985). Flora of China. Science Press, Beijing. 